\title{
The utilization of thiocyanate as a nitrogen source by a heterotrophic bacterium: the degradative pathway involves formation of ammonia and tetrathionate
}

\author{
Jane Stratford, Ana E. X. O. Dias and Christopher J. Knowles \\ Author for correspondence: Jane Stratford. Tel: +44 227 764000. Fax: +44 227763912.
}

Biological Laboratory, The University, Canterbury, Kent CT2 7NJ, UK

\begin{abstract}
A Gram-negative soil bacterium (isolate 26B) has been shown to utilize up to $100 \mathrm{mM}$ thiocyanate as a source of nitrogen when supplied with glucose as the source of carbon and energy. During growth of isolate 26B with thiocyanate as the source of nitrogen, no ammonia, nitrate, nitrite, cyanide, cyanate, sulfate, sulfite, sulfide or carbonyl sulfide was detected in the growth medium. Growth of the bacterium on ${ }^{14} \mathrm{C}$-labelled thiocyanate $(1.6 \mu \mathrm{Ci})$ and glucose, yielded ${ }^{14} \mathrm{C}$-labelled carbon dioxide $(0.9 \mu \mathrm{Ci})$. The addition of $2.9 \mathrm{mM}$ thiocyanate to a bacterial suspension in phosphate buffer (50 mM, pH 7.4) resulted in the utilization of $2.1 \mathrm{mM}$ thiocyanate and the production of $2.0 \mathrm{mM}$ ammonia. This activity was inducible and only occurred after growth of the bacterium with thiocyanate as the source of nitrogen. Tetrathionate $(0.7 \mathrm{mM})$ was detected in the medium after the utilization of thiocyanate $(2.4 \mathrm{mM})$ by a suspension of the bacterium in phosphate buffer, and thiosulfate (1.0 mM) was detected as an intermediate. The addition of sulfide or thiosulfate to the bacterial suspension also resulted in the formation of tetrathionate. The utilization of both of these compounds appeared to be constitutive. A pathway for thiocyanate utilization by isolate 26B is proposed which involves the hydrolysis of thiocyanate to produce cyanate and sulfide. The cyanate then undergoes further hydrolysis to form ammonia and carbon dioxide. The sulfide is ultimately oxidized to tetrathionate via a pathway which includes thiosulfate.
\end{abstract}

Keywords: thiocyanate, heterotrophic utilization, tetrathionate

\section{INTRODUCTION}

Thiocyanate is a toxic anion which arises from a diverse range of natural and industrial sources. In both animals and plants it occurs as the non-functional detoxification product from cyanide ingestion, or as a defence mechanism against microbial infection (Wood, 1975; Westley, 1981). Industrial sources of thiocyanate-containing effluents are widespread, but one of the major sources of such wastes is the carbonization of coal to produce coke. Cyanide reacts readily with sulfur to produce thiocyanate, and any industry with cyanide in its waste is a potential source of thiocyanate contamination. Such industries include steel manufacture, metal mining and electroplating.

Although thiocyanate is less toxic than cyanide, thio- cyanate-containing wastes are produced in vast quantities. Thiocyanate must either be removed totally from effluents or have its concentration greatly reduced in wastes prior to their disposal as it can inhibit the degradation of other pollutants present in the waste and has a detrimental effect on aquatic flora and fauna.

Little is known about the microbial degradation of thiocyanate. Few isolates with the ability to utilize it have been described, and the biochemical pathways involved in thiocyanate degradation are poorly understood. The majority of organisms that have been studied were originally isolated from sludges which had previously been exposed to thiocyanate-containing wastes (Betts et al., 1979).

Thiocyanate can support the autotrophic growth of some micro-organisms which utilize it as the sole source of 
carbon and energy. Thiobacillus thiocyanoxidans (now reclassified as T. thioparus) was isolated from coke oven liquor and was reported to use thiocyanate as both a carbon and nitrogen source (Happold \& Key, 1937). Another autotrophic bacterium, Thiobacillus thioparus strain TK-21, can utilize up to $50 \mathrm{mM}$ thiocyanate (Katayama \& Kuraishi, 1978). A consortium of Bacillus and Pseudomonas species has also been shown to utilize thiocyanate autotrophically (Paruchuri et al., 1990).

Other bacteria, while not able to use thiocyanate as an energy source, have been reported to utilize it during heterotrophic growth. A Pseudomonas stutzeri-like organism (Stafford \& Callely, 1969) and an Artbrobacter species (Betts et al., 1979) can utilize thiocyanate as a source of nitrogen, whereas a strain of Neisseria meningitidis can utilize it as the sole source of sulfur (Port $e t$ al., 1984).

The biochemical pathways involved during the autotrophic utilization of thiocyanate are not known. Youatt (1954) suggested a possible pathway for the utilization of thiocyanate by $T$. thiocyanoxidans in which thiocyanate is hydrolysed to produce cyanate and sulfide. The cyanate undergoes further hydrolysis to form ammonia and carbon dioxide, a step that involves the enzyme cyanase (EC 4.3.99.1). The sulfide produced is oxidized to form sulfate. It has been suggested that the oxidation of sulfide to sulfate is the only energy-yielding step allowing autotrophic growth (Kelly \& Baker, 1990).

Recently, a second pathway for thiocyanate utilization by $T$. thioparus has been proposed which involves a thiocyanate hydrolase enzyme that produces carbonyl sulfide and ammonia (Katayama et al., 1992). This hypothesis is supported by evidence that thiocyanate breakdown in the environment can yield carbonyl sulfide. Investigations by Banwart \& Bremner (1976) showed that carbonyl sulfide was released when thiocyanate was incubated with soils and manures.

A pathway for thiocyanate utilization by heterotrophic micro-organisms has not been proposed. The present investigation concerns the utilization of thiocyanate by a novel heterotrophic soil isolate (26B). This bacterium has been shown to utilize unusually high concentrations of thiocyanate as a source of nitrogen when supplied with a carbon and energy source such as glucose (Dias, 1993). A potential pathway is presented for the utilization of thiocyanate by the isolate, which differs from the above pathways for thiocyanate utilization by autotrophic bacteria.

\section{METHODS}

Isolation of the bacterial isolate (26B). The bacterium, a Gram-negative short rod, was isolated from woodland soil by enrichment culture (Dias, 1993).

Growth of bacterial isolate 26B. Growth of isolate 26B was in a liquid medium consisting of M9 salts (Miller, 1972), $0 \cdot 1 \%$ (v/v) trace elements (Bauchop \& Elsden, 1960), $10 \mathrm{mM}$ glucose as the source of carbon and energy, and $3 \mathrm{mM} \mathrm{KSCN}$ (or $\mathrm{NH}_{4} \mathrm{Cl}$ where indicated) as the source of nitrogen. Growth was in
$250 \mathrm{ml}$ conical flasks containing $100 \mathrm{ml}$ medium or 21 conical flasks containing $800 \mathrm{ml}$ medium, incubated at $30^{\circ} \mathrm{C}$ on an orbital shaker (200 r.p.m.). Growth was monitored by the optical density at $610 \mathrm{~nm}$. Growth in sulfur-free mineral salts medium was as above but all sulfate salts were replaced by chloride salts.

Preparation of bacterial cell suspensions. Isolate $26 \mathrm{~B}(800 \mathrm{ml})$ was grown to the mid-exponential phase of growth $\left(\mathrm{OD}_{610} 0 \cdot 8\right)$. Bacteria were harvested by centrifugation at $15000 \mathrm{~g}$ for $15 \mathrm{~min}$ at $4{ }^{\circ} \mathrm{C}$. The cells were washed twice in phosphate buffer (pH 7.4, $50 \mathrm{mM}$ ), and finally resuspended in $90 \mathrm{ml}$ of the same buffer. The resuspended cells were divided into $3 \times 30 \mathrm{ml}$ aliquots in $100 \mathrm{ml}$ conical flasks, and $3 \mathrm{mM} \mathrm{KSCN}$ (or other compound under investigation, as indicated) was added. The flasks were incubated at $30^{\circ} \mathrm{C}$ on an orbital shaker (200 r.p.m.).

Chemical analyses. At specified time intervals, either 2 or $3 \mathrm{ml}$ medium was aseptically removed from the sample flasks. Bacteria were removed by centrifugation and the cell-free medium was assayed. Glucose was assayed using the Glucose GOD-PERID diagnostic reagents (Boehringer Mannheim). Thiocyanate was assayed by the method of Stafford \& Callely (1969). Ammonia was determined by the assay of Fawcett \& Scott (1960). Thiosulfate and tetrathionate were determined by the cyanolysis method of Kelly et al. (1969). Sulfate was determined by the method of Rand et al. (1975). Sulfide and sulfite were assayed by the method described by Truper \& Schlegel (1964), and elemental sulfur by the method of Schedel \& Truper (1980). Carbonyl sulfide was detected using a carbonyl sulfide analysis tube with a sensitivity of 2 to 200 p.p.m.

Analysis of the production of carbon dioxide from ${ }^{14} \mathrm{C}$ labelled thiocyanate. Isolate 26B was grown in $250 \mathrm{ml}$ conical flasks containing a centre well. The flasks contained $100 \mathrm{ml}$ medium with $10 \mathrm{mM}$ glucose, $3 \mathrm{mM} \mathrm{KSCN}$ and $1.6 \mu \mathrm{Ci}$ $(59 \cdot 2 \mathrm{kBq}){ }^{14} \mathrm{C}$-labelled $\mathrm{KSCN}$. The centre well of the flasks contained $1 \mathrm{M} \mathrm{NaOH}(10 \mathrm{ml})$ as a $\mathrm{CO}_{2}$ trap. The flasks were sealed with rubber septa and incubated at $30^{\circ} \mathrm{C}, 200$ r.p.m. At the end of the specified incubation period, $5 \mathrm{M} \mathrm{HCl}(5 \mathrm{ml})$ was added to the medium in the flasks to terminate biochemical activity and to release dissolved carbon dioxide. The flasks were shaken on the orbital shaker for a further $3 \mathrm{~h}$ to allow all of the $\mathrm{CO}_{2}$ produced to enter the alkali trap. Aliquots $(1 \mathrm{ml})$ of both the medium and the trap were added to $4 \mathrm{ml}$ Optiphase 'Hisafe' 3 scintillation fluid and the radioactivity was measured in a liquid scintillation counter (Pharmacia, WALLAC 1410).

Chemicals. All chemicals were supplied by Sigma, except ${ }^{14} \mathrm{C}$ labelled $\mathrm{KSCN}$, which was supplied by Amersham, and Optiphase Scintillation fluid, which was supplied by LKB Scintillation Products. Carbonyl sulfide analysis tubes were supplied by GAS TEK.

\section{RESULTS}

\section{Taxonomy and identification of isolate 26B}

The novel soil bacterium 26B is a Gram-negative short rod that shows positive results to the catalase and oxidase tests. The colonies on solid medium are round, entire, smooth, shiny and convex (Dias, 1993). The metabolism of carbohydrates by isolate $26 \mathrm{~B}$ was determined by measuring growth in an API $50 \mathrm{CH}$ system incubated at $30^{\circ} \mathrm{C}$ for $48 \mathrm{~h}$. The organism oxidized 16 of the 48 carbohydrates tested including glycerol, arabinose, galactose, glucose, fructose, mannose, mannitol, maltose, 


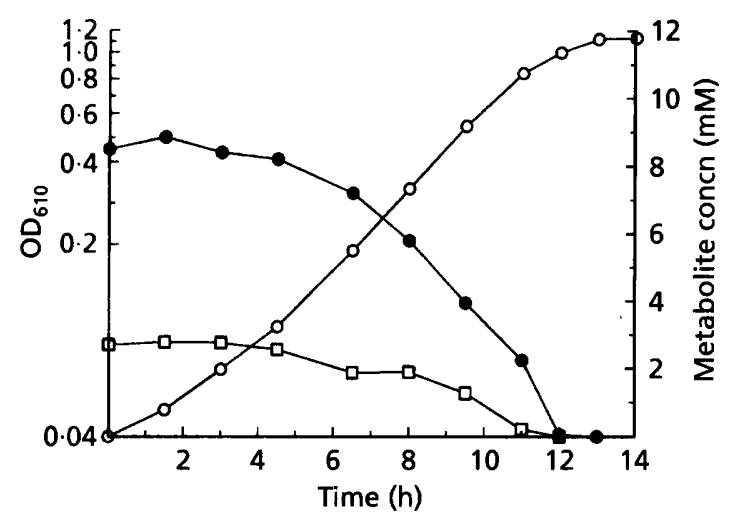

Fig. 1. Growth $(O)$ of isolate $26 \mathrm{~B}$ in mineral salts liquid medium with $9 \mathrm{mM}$ glucose (O) as the carbon and energy source and $3 \mathrm{mM}$ thiocyanate $(\square)$ as the nitrogen source. Growth was in $100 \mathrm{ml}$ medium in $250 \mathrm{ml}$ conical flasks at $30^{\circ} \mathrm{C}, 200$ r.p.m. No ammonia or sulfate was detected in the medium.

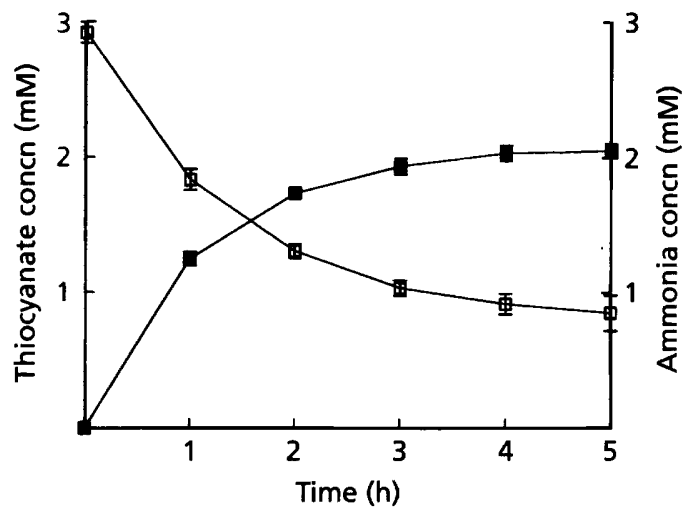

Fig. 2. Ammonia formation ( $\square$ ) from thiocyanate $(\square)$ by a bacterial suspension in phosphate buffer $(50 \mathrm{mM}, \mathrm{pH} 7.4)$. Bacteria were grown in liquid medium with $10 \mathrm{mM}$ glucose and $3 \mathrm{mM}$ thiocyanate as described in Methods. Cells were harvested at mid-exponential growth, washed in phosphate buffer $(50 \mathrm{mM}, \mathrm{pH} 7.4)$ and resuspended to $10 \%$ of the original volume in the same buffer. The bacterial suspension $(30 \mathrm{ml})$ was incubated with $2.9 \mathrm{mM}$ thiocyanate in $150 \mathrm{ml}$ conical flasks at $30^{\circ} \mathrm{C}, 200$ r.p.m. Error bars represent the standard deviation $(n-1)$ between three replicate samples.

fucose and gluconate. The bacterium was also analysed using an API 20E test system, a miniaturized assay containing 23 standard biochemical tests for the identification of Enterobacteriaceae and other Gram-negative bacteria. Isolate $26 \mathrm{~B}$ showed positive results for arginine dehydrogenase, citrate utilization, and urease, but negative results for lysine decarboxylase, ornithine decarboxylase, tryptophan deaminase and metabolism, VogesProskauer and gelatin liquefaction. The API profile of the isolate identified it as a Pseudomonas fuorescens. However, this result seemed in doubt because the bacterium was non-motile, did not produce a fluorescent pigment and its morphology was atypical of a fluorescent Pseudomonas species. The isolate was therefore sent to the National Collection of Industrial and Marine Bacteria, Aberdeen, UK (NCIMB) for identification, but after five stages of tests including gas chromatography of the fatty acid profile, the bacterium could not be confidently placed under any of the common bacterial genera (Dias, 1993). The major acids present in isolate $26 \mathrm{~B}$ were hexadecanoic acid $\left(C_{16: 0} 23.9 \%\right)$, hexadecanoic acid $\left(C_{16: 1} 31 \%\right)$, octadecanoic acid $\left(\mathrm{C}_{18: 1} 12 \%\right)$ and possibly a cyclopropane acid $\left(\mathrm{C}_{17: 0} 15 \%\right)$.

\section{Growth of 26B on thiocyanate}

Isolate $26 \mathrm{~B}$ was able to utilize thiocyanate as the sole source of nitrogen when supplied with glucose as the source of carbon and energy. Figure 1 shows the growth of isolate $26 \mathrm{~B}$ on $9 \mathrm{mM}$ glucose and $3 \mathrm{mM} \mathrm{KSCN}$. Thiocyanate and glucose utilization occurred throughout growth of the bacterium after a short lag phase. On $3 \mathrm{mM}$ thiocyanate, isolate $26 \mathrm{~B} \mathrm{had}$ a doubling time of $2.5 \mathrm{~h}$. The bacterium could utilize concentrations of thiocyanate of up to $100 \mathrm{mM}$. No ammonia, nitrate, nitrite, cyanide or cyanate production was detected in the growth medium, no detectable odorous (sulfurous) gases, including carbonyl sulfide, were produced, and there was no appreciable change in $\mathrm{pH}$ of the growth medium.

Isolate $26 \mathrm{~B}$ was also able to utilize thiocyanate as the source of nitrogen and sulfur, or as the sole source of sulfur when supplied with $3 \mathrm{mM}$ ammonia as the source of nitrogen, but with a longer lag phase of up to $30 \mathrm{~h}$. Thiocyanate was utilized throughout the growth of the bacterium and the doubling time was $8.8 \mathrm{~h}$. Again, no ammonia, carbonyl sulfide, cyanide, cyanate or sulfate were detected in the growth medium.

\section{Formation of ammonia from thiocyanate}

Unlike the growing bacteria, when thiocyanate was added to a suspension, in phosphate buffer $(50 \mathrm{mM}, \mathrm{pH} 7 \cdot 4)$, of isolate 26B which had originally been grown with $3 \mathrm{mM}$ thiocyanate as the source of nitrogen and harvested at the mid-exponential phase of growth $\left(\mathrm{OD}_{610}=0.8\right)$, ammonia was produced (Fig. 2). The conversion of thiocyanate to ammonia was complete after approximately $4 \mathrm{~h}$ and $2.0 \mathrm{mM}$ ammonia was produced from the utilization of $2.1 \mathrm{mM}$ thiocyanate. However, when thiocyanate was added to a suspension of isolate $26 \mathrm{~B}$ in phosphate buffer ( $50 \mathrm{mM}, \mathrm{pH} 7 \cdot 4$ ) which had originally been grown with $3 \mathrm{mM}$ ammonia as the source of nitrogen, no thiocyanate utilization occurred and no ammonia formation was detected.

\section{Formation of carbon dioxide from thiocyanate}

The formation of carbon dioxide from thiocyanate was followed by the addition of ${ }^{14} \mathrm{C}$-labelled $\mathrm{KSCN}$ to the thiocyanate $(3 \mathrm{mM})$ in the growth medium as the source of nitrogen. Throughout growth of the bacterium, radioactivity in the medium decreased at a rate which paralleled the rate of thiocyanate utilization (Fig. 3). The 


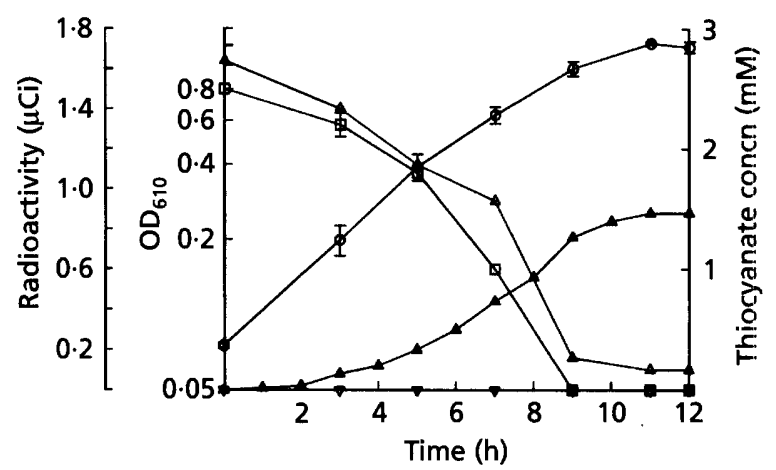

Fig. 3. Formation of ${ }^{14} \mathrm{C}$-labelled carbon dioxide during growth (O) of isolate $26 \mathrm{~B}$ in liquid medium on $10 \mathrm{mM}$ glucose and $3 \mathrm{mM}$ thiocyanate $(\square)$ with ${ }^{14} \mathrm{C}$-labelled thiocyanate added, as described in Methods. ${ }^{14} \mathrm{C}$ activity was monitored in cell-free medium $(\triangle)$, in the sodium hydroxide trap $(\Delta)$ and in the bacterial cells $(\nabla)$. Error bars represent SD $(n-1)$ between three replicate samples.

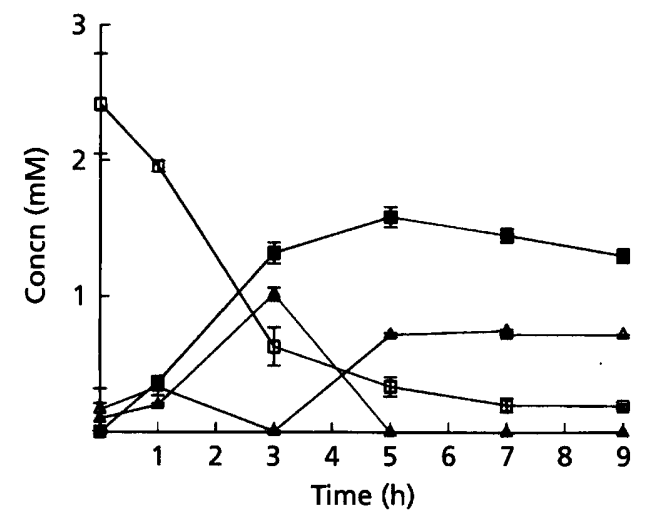

Fig. 4. Thiocyanate $(\square)$ utilization and tetrathionate $(\triangle)$ and ammonia ( $\square$ ) formation by a bacterial suspension in phosphate buffer $(50 \mathrm{mM}, \mathrm{pH} 7 \cdot 4)$. The bacterial suspension was prepared and incubated as indicated for Fig. 2. Thiosulfate $(\boldsymbol{\Delta})$ was detected in the medium as an intermediate. Error bars represent SD $(n-1)$ between three replicate samples.

radioactivity detected in the alkali trap increased throughout growth, indicating that carbon dioxide was produced from thiocyanate. During growth, the radioactivity in the medium decreased from 1.6 to $0.1 \mu \mathrm{Ci}$, whereas the amount of radioactivity recovered in the trap was $0.9 \mu \mathrm{Ci}$. At no time was any ${ }^{14} \mathrm{C}$ detected in association with the washed bacterial cells, nor was it detected as another compound in the medium, suggesting that the major product was gaseous (carbon dioxide).

\section{Formation of tetrathionate from thiocyanate}

The utilization of thiocyanate by isolate 26B during growth or when suspended in phosphate buffer did not lead to formation of the sulfur-containing products expected in the medium. Products assayed for included sulfate, sulfide, sulfite, elemental sulfur and carbonyl
Table 1. Rate of utilization of reduced inorganic sulfur compounds by suspensions of isolate 26B

Bacteria were grown in liquid medium with $10 \mathrm{mM}$ glucose and $3 \mathrm{mM}$ thiocyanate or ammonia as nitrogen source, as described in Methods. They were harvested at the mid-exponential phase of growth, washed in phosphate buffer $(50 \mathrm{mM}, \mathrm{pH} 7 \cdot 4)$ and resuspended to $10 \%$ original volume in the same buffer. The inorganic sulfur compound ( $3 \mathrm{mM}$ ) was added to $30 \mathrm{ml}$ bacterial suspension in $150 \mathrm{ml}$ conical flasks and incubated at $30^{\circ} \mathrm{C}, 200$ r.p.m. At $30 \mathrm{~min}$ intervals ( $10 \mathrm{~min}$ intervals for sulfide), 2 or $3 \mathrm{ml}$ samples were removed from the flasks, centrifuged to remove bacteria and the cell-free supernatants were assayed for the sulfur compound and tetrathionate as described in Methods. Sulfide utilization rates have been corrected for auto-oxidation of sulfide.

\begin{tabular}{|lcc|}
\hline $\begin{array}{l}\text { Sulfur } \\
\text { compound }\end{array}$ & $\begin{array}{c}\text { Activity }\left[\mu \mathrm{mol} \mathrm{S} \mathrm{cpd} \mathrm{removed} \mathbf{h}^{-1}\right. \\
(\mathbf{m g} \text { cell dry wt) })^{-\mathbf{1}} \text { ] of: }\end{array}$ \\
\cline { 2 - 3 } & $\begin{array}{c}\text { Thiocyanate-grown } \\
\text { cells }\end{array}$ & $\begin{array}{c}\text { Ammonia-grown } \\
\text { cells }\end{array}$ \\
\hline $\mathrm{SCN}^{-}$ & 0.27 & 0 \\
$\mathrm{~S}^{2-}$ & 28.5 & 8.9 \\
$\mathrm{~S}_{\mathbf{2}} \mathrm{O}_{3}^{2-}$ & 0.62 & 0.82 \\
$\mathrm{~S}_{\mathbf{4}} \mathrm{O}_{\mathbf{6}}^{\mathbf{2}}$ & 0 & 0 \\
\hline
\end{tabular}

sulfide. The medium was therefore assayed for other sulfur-containing products including thiosulfate and tetrathionate.

Tetrathionate was produced from thiocyanate by thiocyanate-grown suspensions of isolate $26 \mathrm{~B}$ in phosphate buffer $(50 \mathrm{mM}, \mathrm{pH} 7 \cdot 4)$, and thiosulfate (up to $1 \cdot 0 \mathrm{mM}$ ) was detected as an intermediate (Fig. 4). The utilization of $2.4 \mathrm{mM}$ thiocyanate gave rise to $0.7 \mathrm{mM}$ tetrathionate, suggesting that there is a high degree of conversion to tetrathionate (i.e. $4 \times \mathrm{SCN}^{-} \rightarrow 1 \times \mathrm{S}_{4} \mathrm{O}_{6}^{2-}$ ). Stoichiometric conversion of thiocyanate to tetrathionate was also shown by growing cells of isolate $26 \mathrm{~B}$, and tetrathionate was produced from thiocyanate utilized as a source of sulfur by the bacterium.

\section{Utilization of reduced sulfur compounds}

The rates of utilization of thiocyanate, thiosulfate, tetrathionate and sulfide by suspensions of bacteria that had originally been grown with either thiocyanate or ammonia as the source of nitrogen are shown in Table 1. Thiocyanate, thiosulfate and sulfide were all converted to tetrathionate by bacterial suspensions in phosphate buffer $(50 \mathrm{mM}, \mathrm{pH} 7 \cdot 4)$. Thiocyanate was utilized at a rate of $0 \cdot 27 \mu$ mol thiocyanate $\mathrm{h}^{-1}(\mathrm{mg} \text { cell dry wt })^{-1}$ by cells that had originally been grown on thiocyanate, but was not utilized by cells originally grown on ammonia. Thiosulfate $(3.8 \mathrm{mM})$ was converted to tetrathionate $(2.0 \mathrm{mM})$ at similar rates of 0.62 and $0.82 \mu \mathrm{mol}$ thiosulfate $\mathrm{h}^{-1}(\mathrm{mg}$ cell dry $w t)^{-1}$ by bacteria grown on either thiocyanate or ammonia. The rate of sulfide utilization by thiocyanate grown cells was $28.5 \mu \mathrm{mol}$ sulfide $\mathrm{h}^{-1}$ (mg cell dry wt $)^{-1}$, more than threefold higher than for ammonia-grown 
cells: $8.9 \mu \mathrm{mol}$ sulfide $\mathrm{h}^{-1}$ (mg cell dry wt $)^{-1}$. A concentration of $0.7 \mathrm{mM}$ tetrathionate was produced from $2.1 \mathrm{mM}$ sulfide by the bacterial suspension and thiosulfate $(0.4 \mathrm{mM})$ was detected as an intermediate.

Tetrathionate was not utilized when added to suspensions of bacteria that had been grown on either thiocyanate or ammonia, although the addition of $5 \mathrm{mM}$ tetrathionate to thiocyanate-grown bacterial suspensions did not inhibit the utilization of $3 \mathrm{mM}$ thiocyanate, thiosulfate or sulfide.

\section{DISCUSSION}

Isolate $26 \mathrm{~B}$ has been shown to utilize thiocyanate during heterotrophic growth as the sole source of either nitrogen and/or sulfur when supplied with a carbon and energy source such as glucose. During the growth of this isolate on thiocyanate as the source of nitrogen none of the compounds (ammonia, cyanate, sulfide, sulfate or carbonyl sulfide) suggested by Youatt (1954) or Katayama et al. (1992) as possible products from the utilization of thiocyanate by autotrophs were detected in the growth medium. This was unusual, as Happold et al. (1954) showed ammonia formation from thiocyanate by a Thiobacillus species and Paruchuri et al. (1990) observed an $89 \%$ conversion of thiocyanate-nitrogen to ammonia by a microbial consortium utilizing thiocyanate autotrophically. Sulfate was detected in the medium after the growth of a heterotrophic Pseudomonas stutzeri-like organism on thiocyanate (Stafford \& Callely, 1969) and a 92\% conversion of thiocyanate-sulfur to sulfate was shown by the above consortium (Paruchuri et al., 1990).

Unlike growing bacteria, when thiocyanate was added to a bacterial suspension in phosphate buffer $(50 \mathrm{mM}$, $\mathrm{pH} 7.4$ ) that had originally been grown with $3 \mathrm{mM}$ thiocyanate as the source of nitrogen, ammonia formation was detected. The production of ammonia from thiocyanate was stoichiometric. In contrast, the addition of thiocyanate to a cell suspension that had originally been grown with $3 \mathrm{mM}$ ammonia as the source of nitrogen did not result in any thiocyanate utilization or ammonia formation showing that thiocyanate utilization by isolate $26 \mathrm{~B}$ is inducible.

Carbon dioxide has also been shown to be a degradation product of thiocyanate by isolate $26 \mathrm{~B}$. Only $57 \%$ of the initial ${ }^{14} \mathrm{C}$ added to the growth medium in the form of labelled thiocyanate was recovered in the carbon dioxide trap. However, at no time was any ${ }^{14} \mathrm{C}$ detected either associated with washed bacterial cells or as another component of the medium. The reason for the discrepancy in ${ }^{14} \mathrm{C}$ recovery is not clear, but could be due to incomplete carbon dioxide trapping.

The ultimate product of the sulfur moiety of the thiocyanate utilized as a source of nitrogen by this organism is tetrathionate. Tetrathionate was produced from thiocyanate by both growing cells and suspensions of bacteria that had been grown on thiocyanate, and thiosulfate was detected as an intermediate. To our knowledge, there have been no previous reports of tetrathionate production as the final product of thio- cyanate utilization by bacteria. Sulfate has been suggested (Youatt, 1954; Stafford \& Callely, 1969) as the final product, as has carbonyl sulfide (Katayama et al., 1992). Tetrathionate was also produced from thiocyanate utilized as a source of sulfur by the bacterium; however at present it is not known whether the pathway of utilization of thiocyanate as a S-source is the same as the pathway of its utilization as an $\mathrm{N}$-source. The addition of either sulfide or thiosulfate to suspensions of the isolate grown on thiocyanate as the source of nitrogen also resulted in the formation of tetrathionate, suggesting that both compounds could be intermediates in the production of tetrathionate from thiocyanate. Thiosulfate is an intermediate as it was detected in the medium during thiocyanate utilization. A study of the utilization rates of these sulfur compounds by suspensions of the bacterium suggested that thiocyanate utilization is inducible, whereas the ability to oxidize thiosulfate to tetrathionate is constitutive. The conversion of sulfide to tetrathionate is also greater in thiocyanate grown cells than in ammonia grown cells.

It has been suggested that thiosulfate and tetrathionate could be intermediates in the oxidation of thiocyanate to sulfate by an autotrophic consortium (Paruchuri et al., 1990), although this pathway was not demonstrated. Thiosulfate can be utilized by thiocyanate-utilizing organisms (Paruchuri et al., 1990; Happold et al., 1954; Youatt, 1954), and Katayama \& Kuraishi (1978) reported that thiosulfate inhibited thiocyanate utilization by $T$. thioparus. However, in these cases sulfate was suggested as the final product of the sulfur moiety of thiocyanate. The ability to oxidize thiosulfate to sulfate via tetrathionate has been demonstrated in many organisms, especially the thiobacilli. Wood \& Kelly (1986) and Lu \& Kelly (1988) showed oxidation of thiosulfate to sulfate with the obligatory formation of tetrathionate as an intermediate in T. tepidarius. They showed that thiosulfate oxidation to tetrathionate occurs in the periplasm whereas further oxidation of tetrathionate to sulfate occurs after transport to the cytoplasmic side of the membrane. Thiosulfate conversion to tetrathionate without further oxidation to sulfate has been shown to occur in a variety of heterotrophic bacteria (Mason \& Kelly, 1988).

The physiological function of tetrathionate formation by isolate $26 \mathrm{~B}$ is unclear. It would appear that this isolate lacks the enzymes to enable it to further oxidize tetrathionate to sulfate. This could be a membrane transport effect as it has been suggested that thiocyanate inhibits the oxidation of tetrathionate to sulfate in $T$. tepidarius by dissipating the transmembrane electrochemical potential (Lu \& Kelly, 1988). The ability of heterotrophic microorganisms to oxidize thiosulfate to tetrathionate has been proposed to have energetic or ecological advantages (Mason \& Kelly, 1988).

Thiocyanate degradation by the novel isolate $26 \mathrm{~B}$ has been previously shown (Stratford et al., 1992) to be associated with a stimulation in the cyanase activity of this organism, suggesting that the degradation pathway is via cyanate (Fig. 5). Thiocyanate is hydrolysed to cyanate and sulfide. The cyanate then undergoes hydrolysis to form 


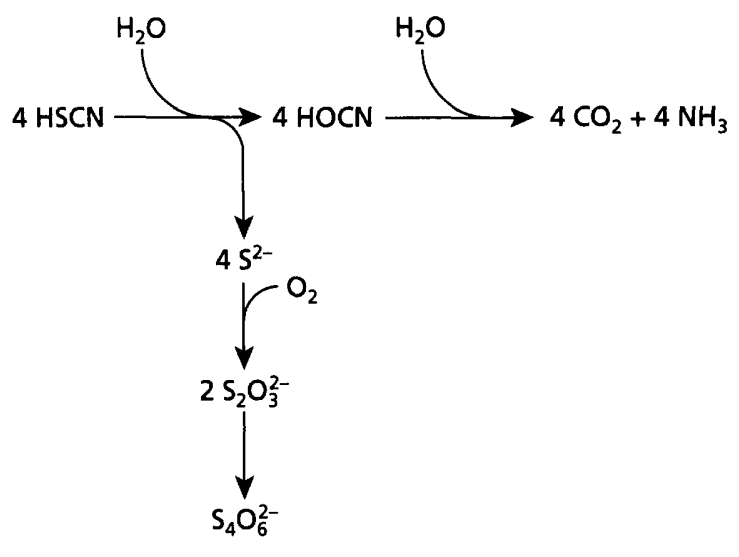

Fig. 5. Proposed pathway for thiocyanate utilization by the heterotrophic bacterium 26B. Thiocyanate is hydrolysed to cyanate and sulfide by an inducible enzyme. Cyanate is hydrolysed further to carbon dioxide and ammonia by cyanase (EC 4.3.99.1). Cyanase activity in isolate 26B is also inducible and has been shown to hydrolyse cyanate under anaerobic conditions. Sulfide is oxidized to produce tetrathionate via the formation of thiosulfate. The ability to convert thiosulfate to tetrathionate is constitutive. No further oxidation of tetrathionate was observed.

ammonia and carbon dioxide. The sulfide is oxidized to produce tetrathionate via thiosulfate. The ability to utilize thiocyanate, and cyanase activity in this bacterium is inducible (Stratford et al., 1992), but the oxidation of thiosulfate appears to be constitutive. This pathway is similar to that proposed by Youatt (1954) in that cyanate is an intermediate; however, tetrathionate is the final product of the sulfur moiety of thiocyanate.

\section{ACKNOWLEDGEMENTS}

This work was supported by a studentship from the Science and Engineering Research Council (UK) to J. S. and by a studentship from the Conselho de Pesquisa, Brazil to A.E.X.O.D. We also wish to thank Professor Donovan Kelly (Warwick University), Dr Anne Wood (University of London) and Dr John Ingledew (University of St Andrews) for helpful discussions.

\section{REFERENCES}

Banwart, W. L. \& Bremner, J. M. (1976). Evolution of volatile sulfur containing compounds from soils treated with sulfur containing materials. Soil Biol Biochem 8, 439-445.

Bauchop, T. \& Elsden, S. R. (1960). The growth of microorganisms in relation to energy supply. $J$ Gen Microbiol 25, 457-469.

Betts, P. M., Rinder, D. F. \& Fleeker, J. R. (1979). Thiocyanate utilisation by an Artbrobacter. Can J Microbiol 25, 1277-1282.

Dias, A. E. X. O. (1993). Thiocyanate degradation by a novel isolate. $\mathrm{PhD}$ thesis, University of Kent, UK.
Fawcett, J. K. \& Scott, J. E. (1960). A rapid and precise method for the determination of urea. J Clin Pathol 13, 156-159.

Happold, F. C., Johnstone, K. I., Rogers, A. J. \& Youatt, J. B. (1954). The isolation and characteristics of an organism oxidising thiocyanate. J Gen Microbiol 10, 261-266.

Happold, F. C. \& Key, A. (1937). The bacterial purification of gas works liquors. II. The biological oxidation of ammonium thiocyanate. Biochem J 31, 1323-1329.

Katayama, Y. \& Kuraishi, H. (1978). Characteristics of Thiobacillus thioparus and its thiocyanate assimilation. Can J Microbiol 24, 804-810.

Katayama, Y., Narahara, Y., Inoue, Y., Amano, F., Kanagawa, T. \& Kuraishi, H. (1992). A thiocyanate hydrolase of Thiobacillus thioparus. J Biol Chem 267 (13), 9170-9175.

Kelly, D. P. \& Baker, S. C. (1990). The organosulfur cycle: aerobic and anaerobic processes leading to the turnover of C1-sulfur compounds. FEMS Microbiol Rev 87, 241-246.

Kelly, D. P., Chambers, L. A. \& Trudinger, P. A. (1969). Cyanolysis and spectrophotometric estimation of trithionate in mixture with thiosulfate and tetrathionate. Anal Cbem 41, 898-901.

Lu, W.-P. \& Kelly, D. P. (1988). Kinetic and energetic aspects of inorganic sulfur compound oxidation by Thiobacillus tepidarius. $J$ Gen Microbiol 134, 865-876.

Mason, J. \& Kelly, D. P. (1988). Thiosulfate oxidation by obligately heterotrophic bacteria. Microb Ecol 15, 123-134.

Miller, J. H. (1972). In Experiments in Molecular Genetics, pp. 431-433. Cold Spring Harbor, NY: Cold Spring Harbor Laboratory.

Paruchuri, Y. L., Shivaraman, N. \& Kumaran, P. (1990). Microbial transformation of thiocyanate. Environ Pollut 68, 15-28.

Port, J. L., DeVoe, I. W. \& Archibald, F. S. (1984). Sulfur acquisition by Neisseria meningitidis. Can J Microbiol 30, 1453-1457.

Rand, M. C., Greenburg, A. E. \& Taros, M. J. (1975). In Standard Methods for the Examination of Waste-water, 14th edn, pp. 496-498. Washington, DC: American Public Health Association.

Schedel, M. \& Truper, H. G. (1980). Anaerobic oxidation of thiosulfate and elemental sulfur in Thiobacillus denitrificans. Arch Microbiol 124, 205-210.

Stafford, D. A. \& Callely, A. G. (1969). The utilisation of thiocyanate by a heterotrophic bacterium. J Gen Microbiol 55, 285-289.

Stratford, J., Dias, A. E. X. O. \& Knowles, C. J. (1992). Microbial degradation of thiocyanate. In Proceedings of IGT 5th International Symposium on Gas, Oil and Environmental Biotechnology, Chicago.

Truper, H. G. \& Schlegel, H. G. (1964). Sulfur metabolism in Thiorhodaceae. I. Quantitative measurements on growing cells of Chromatium okenii. Antonie Leeuwenboek 30, 225-238.

Westley, J. (1981). Cyanide and sulfane sulfur. In Cyanide in Biology, pp. 201-212. Edited by B. Vennesland. London: Academic Press.

Wood, J. L. (1975). Biochemistry. In The Chemistry and Biocbemistry of Thiocyanic Acid and its Derivatives, pp. 156-221. Edited by A. A. Newman. New York: Academic Press.

Wood, A. P. \& Kelly, D. P. (1986). Chemolithotrophic metabolism of the newly-isolated moderately thermophilic, obligately autotrophic Thiobacillus tepidarius. Arch Microbiol 144, 71-77.

Youatt, J. B. (1954). Studies on the metabolism of Thiobacillus thiocyanoxidans. J Gen Microbiol 11, 139-149.

Received 21 March 1994; revised 25 May 1994; accepted 13 June 1994. 